\title{
A Pilot Study of the Effect of Otago Exercise Program on Fall Risk and Quality of Life of Older Women
}

\author{
Muammar Irsyad Kadir ${ }^{1 *}$, Nur Hardiyanty ${ }^{1}$, Fadhia Adliah ${ }^{1}$
}

'Department of Physical Therapy, College of Nursing, Universitas Hasanuddin, Makassar, Indonesia

*Corresponding author: Muammar Irsyad Kadir, Department of Physical Therapy, College of Nursing, Universitas Hasanuddin, Makassar, Indonesia; muammar1997@gmail.com
Received : 2021-02-08 Accepted : 2021-04-24 Published : 2021-05-12

\section{INTRODUCTION}

As people get older, they will experience many physiological changes, including hearing loss, vision, breathing, motion problems, and have the risk of chronic diseases such as heart failure, stroke, and dementia. ${ }^{1}$ One of the physical problems that usually prevent older people from carrying out daily activities is a fall accident.

In Indonesia, the fall accident prevalence in the older people group aged over 55 years is reaching $49.4 \%$, and those over 65 years old is reaching $67.1 \%{ }^{2}$ In addition, the restriction of mobility experienced by older people due to the ageing process can make them lose the opportunity to prevent themselves from falling. These limitations can inhibit older people from achieving their welfare and maximizing the quality of life. ${ }^{3}$

Otago Exercise Program is an exercise program that can reduce the number of falls by increasing the strength of the lower limb muscles, increasing balance, and providing walking training to older people. In addition, this exercise is also able to improve the welfare and well-being of older people. ${ }^{4}$ Several previous studies have concluded that providing the Otago exercise program to reduce falls risk was effective.

This study explored the effect of the Otago exercise program on fall risk and quality of life using the paired T-test and independent T-test.

Results: The results showed a significant effect on the risk of fall and the quality of life of the older people in the treatment group. In addition, there were significant different influences on the value of falling risk and quality of life (physical and environmental) between the treatment and control groups.

Conclusion: The 0tago exercise program had a significant effect on reducing the risk of falls and improving the quality of life of older people.

Keywords: older, risk of falling, quality of life

Cite this Article: Kadir, M.I., Hardiyanty, N., Adliah, F. 2021. A Pilot Study of the Effect of Otago Exercise Program on Fall Risk and Quality of Life of Older Women. Physical Therapy Journal of Indonesia 2(1): 1-4. D0l: 10.51559/ptii.v2i1.16

of older women, who are more susceptible to fall and having a lower quality of life than older men because of the lower muscle strength and balance., This study aimed to determine the effect of Otago exercise on falling risk and the quality of life of older women.

\section{METHODS}

This study used an experimental research design using a pretest-posttest with a control group research design. The study was conducted at Panti Werdha Theodora, Makassar, Indonesia, from 17 February to 23 March 2020, with 16 respondents. We divided the participants into two groups of experimental and control groups (Figure 1). The intervention group received the 30 mins of Otago exercise program 3 times per week for 5 weeks. In contrast, the control group did not receive the Otago exercise program but performed the physical activity as usual during the study period. The sample selection used a purposive sampling technique that included women who were being $>65$ years old. The exclusion criteria were those older women who had uncontrolled chronic diseases. All the participants have been informed about the risks and benefits before participating in this study. Each participant obtained the written informed consent. This study design received ethical approval from the Health 
Research Ethics Committee Health Polytechnic Makassar Number: 0066/KEPK-PTKMKS/ III/2020.

Timed up and go test (TUGT) is a measurement of the ability of the elderly in walking and assesses the risk of falling based on a score of $\geq 13.5$ seconds defined as high risk to experience falls. ${ }^{7}$ WHOQOL-BREF is a 26 questions measurement instrument that uses a Likert scale (five points from 1 to 5 ) in each question. WHOQOL-BREF included four domains: (1) physical domain, is in questions number $3,4,10,15,16,17$, and 18 ; (2) the psychological domain, is in questions number

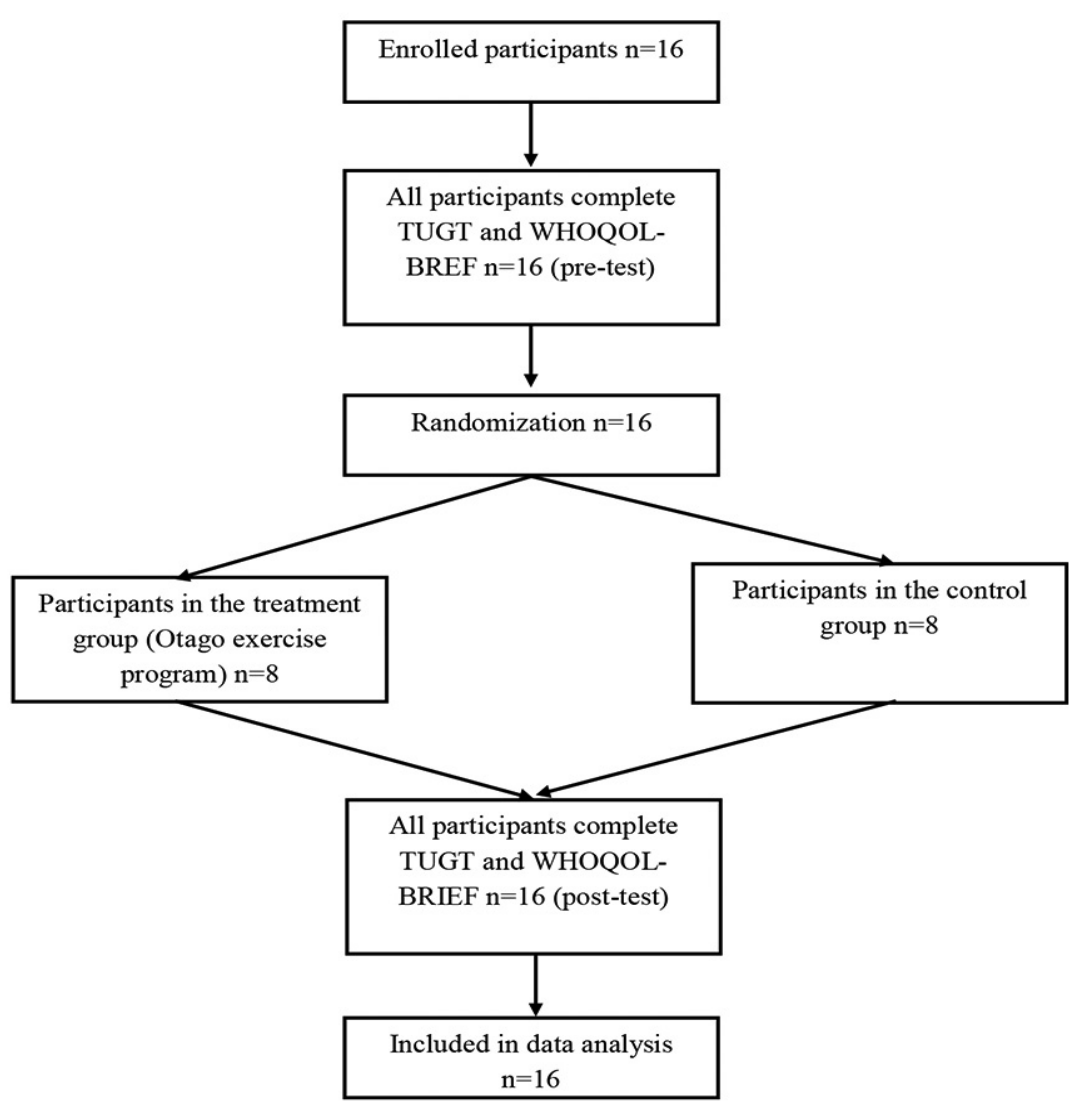

Figure 1. Flow diagram of study participants

Table 1. Characteristics of samples based on age

\begin{tabular}{lccccc}
\hline \multirow{2}{*}{ Sample Characteristics } & \multicolumn{2}{c}{ Treatment group } & \multicolumn{2}{c}{ Control group } & \multirow{2}{*}{$\mathbf{p}^{*}$} \\
\cline { 2 - 5 } & $\mathbf{n}=\mathbf{1 0}$ & $\mathbf{\%}$ & $\mathbf{n = 6}$ & $\mathbf{\%}$ & \\
\hline Age (years) & & & & & \\
Mean $\pm \mathrm{SD}$ & $75.60 \pm 9.003$ & & $76.00 \pm 10,564$ & & 0.617 \\
BMI $\left(\mathrm{kg} / \mathrm{m}^{2}\right)$ & 6 & 60 & 2 & 33.3 & \\
Normal body weight & 2 & 20 & 0 & 0 & \multirow{2}{*}{0.591} \\
Risk becoming obesity & 1 & 10 & 4 & 66.7 & \\
Obesity level I & 1 & 10 & 0 & 0 & \\
Level II obesity & & & & &
\end{tabular}

$\mathrm{n}$, number of samples; $\mathrm{p}^{*}$, independent T-test; $\mathrm{SD}$, standard deviation.
$5,6,7,11,19$, and 26; (3) the social relationships domain, is in questions number 20,21, and 22; (4) environmental domain, is in questions number 8 , $9,12,13,14,23,24,25$. Each domain included the respective-question score in calculating the domain score using the standard formula. ${ }^{8}$ The score in each domain ranged from 0-100.

The Shapiro Wilk was used to evaluate the normality of the data. A paired T-test was used to determine any difference between the pre-test and post-test scores. Then, the independent T-test was employed to determine differences in fall risk and quality of life between the treatment and control groups. All the statistical analyses were performed using SPSS vers. 23 statistical software (IBM Corporation, Armonk, NY).

\section{RESULTS}

The number of respondents was 16 , as shown in Table 1. Based on age, the standard deviation value was smaller than the mean, representing data less varied. In addition, the value of $p>0.05$ shows that the data of age were homogeneous or no significant difference. Based on body mass index (BMI), there were 8 out of 16 samples were outside the normal body weight category. In addition, the value of $p>0.05$ represents that the BMI (body mass index) data were homogeneous or no significant difference.

Table 2 shows the results of a paired T-test in the treatment and control groups. The treatment group had a $p<0.05$, which implies a significant effect to reduce the risk of falling.

Table 3 shows the results on physical, psychological, social, and environmental WHOQOL-BREF domains using a paired t-test. In the treatment group, the results showed that all domains have a $p<0.05$, which means that there is a significant effect to improve the quality of life in the treatment group.

Table 4 shows the results of the different effects of the risk of falling between treatment and control groups using the Independent t-test with a value of $p=0.004$, which means that there is a significantly different effect of reducing the risk of falling between the treatment and the control groups.

Table 5 shows the different effects of quality of life using the Independent $t$-test. The physical and environmental domains had a value of $p<0.05$, which means there are significantly different effects to the physical and environmental domains between the treatment and control groups. However, the psychological and social domains have a value of $p>0.05$, which means there are no significantly different effects to the psychological and social domains between the treatment and control groups. 
Table 2. Results of analysis of the influence based on fall risk

\begin{tabular}{cccc}
\hline Group & $\mathbf{n}$ & MD \pm SD & $\mathbf{p}^{*}$ \\
\hline Treatment & 10 & $2.109 \pm 1,366$ & 0.001 \\
Control & 6 & $0.296 \pm 2.302$ & 0.765 \\
\hline
\end{tabular}

$\mathrm{n}$, number of samples; MD, mean difference; $\mathrm{p}^{\star}$, paired T-test, SD, standard deviation.

Table 3. Results of analysis of influence based on quality of life

\begin{tabular}{lccc}
\hline \multicolumn{1}{c}{ Group } & $\mathbf{n}$ & MD \pm SD & p* $^{*}$ \\
\hline $\begin{array}{l}\text { Physical domain } \\
\text { Treatment }\end{array}$ & 10 & $-20.600 \pm 8.249$ & 0.000 \\
Control & 6 & $0.000 \pm 9.818$ & 1.000 \\
Psychological domain & & & \\
Treatment & 10 & $-3.800 \pm 4.492$ & 0.025 \\
Control & 6 & $3.000 \pm 8.198$ & 0.576 \\
Social domain & 10 & & \\
Treatment & 6 & $-4.167 \pm 10.206$ & 0.012 \\
Control & & & 0.363 \\
Environmental domain & 10 & $-13.200 \pm 4.662$ & 0,000 \\
Treatment & 6 & $-0.333 \pm 12.972$ & 0.952 \\
Control & & & \\
\hline
\end{tabular}

$\mathrm{n}$, number of samples; MD, mean difference; $\mathrm{p}^{*}$, paired T-test; $\mathrm{SD}$, standard deviation.

Table 4. Results of analysis of the different effects of falling risk

\begin{tabular}{cccc}
\hline Group & $\mathrm{n}$ & Posttest $($ Mean \pm SD) & $\mathrm{p}^{*}$ \\
\hline Treatment & 10 & $16.07 \pm 4.521$ & 0.004 \\
Control & 6 & $25.28 \pm 6.314$ & \\
\hline
\end{tabular}

$\mathrm{n}$, number of samples; $\mathrm{p}^{*}$, independent T-test; SD, standard deviation.

Table 5. Results of analysis of different effects on quality of life

\begin{tabular}{lccc}
\multicolumn{1}{c}{ Group } & n & Posttest (Mean \pm SD) & p* \\
\hline Physical domain & & & \\
Treatment & 10 & $70.70 \pm 9.638$ & 0,000 \\
Control & 6 & $43.83 \pm 12.123$ & \\
\hline
\end{tabular}

\begin{tabular}{lccc}
\hline $\begin{array}{l}\text { Psychological domain } \\
\text { Treatment }\end{array}$ & 10 & $60.70 \pm 9.866$ & 0.238 \\
Control & 6 & $54.33 \pm 10.250$ & \\
\hline Social domain & 10 & $47.50 \pm 7.929$ & 0.283 \\
Treatment & 6 & $42.67 \pm 10.073$ & \\
Control & 10 & & 0.027 \\
\hline Environmental domain & 6 & $64.50 \pm 9.823$ & \\
Treatment & $50.33 \pm 13.644$ & \\
Control & & & \\
\hline
\end{tabular}

$\mathrm{n}$, number of samples; $\mathrm{p}^{*}$, independent t-test; SD, standard deviation.

\section{DISCUSSION}

The Otago exercise program for older people significantly influences reducing the risk of falling and improving quality of life. The Otago exercise program can increase the strength of the lower limb and improve balance, gait, and, therefore, ultimately prevent falls in older people. ${ }^{9}$ That is because muscle strength training can strengthen the constructed synthesis muscle to boost the performance of actin and myosin in a myofibril, aiming to intensify the muscle fibres (hypertrophy). ${ }^{10}$ Muscle fibres that experience hypertrophy can increase the metabolic system such as ATP and phosphocreatine, increasing aerobic and anaerobic metabolism and increasing energy and muscle strength so that the older people can support their bodies and maintain their body positions to avoid falling events. ${ }^{10}$

In addition, the Otago exercise program also consists of balance training. Balance training for older people aims to provide adjustments to the body regarding changes in movement that occur by increasing the visual, vestibular, somatosensory, and muscular systems. ${ }^{10}$ Increasing the balance can improve the proprioceptive system so that older people can recognize all the changing movements that occur on their body. ${ }^{11}$ Proprioceptive improvement can affect the body's information system so that the body can recognize various conditions around it and help older people maintain their balance. ${ }^{11}$ In addition, the Otago exercise program can increase muscle's strength in the lower extremities and train the balance of the older people, which can help the older people to make adjustments to their posture, anticipate and coordinate movements that can make an impact on reducing the risk of falling. ${ }^{12}$ Therefore, the Otago exercise program can increase muscle's strength and balance (both dynamic and static balance), which can reduce the risk of falling. Previous studies found that the Otago exercise program improves joint pain and functional movements that promote patients' daily activities without obstacles. ${ }^{13,14}$

Other than increasing muscle's strength and balance, the Otago exercise program can also improve the quality of life of older people. ${ }^{15}$ The provision of the Otago exercise program also showed a significantly different effect on the quality of life, especially on the physical and environmental domains, but not significantly different in psychological and social relationships domains. The possible reason for this finding is the psychological condition of women older adult was influenced by their life goals and ability to manage the stress, while the condition of the social relationship is influenced by the support of family or friends when 
the older people face various problems, ${ }^{16}$ whereas the Otago exercise program is a series of exercises that focus on increasing physical components, namely muscle's strength and balance; thus, it was not significantly increasing the value of all aspects of psychological and social relationships of older people.

The increase of functional abilities can help older people create a safe, peaceful, and healthy environment by improving their environmental conditions. Physical exercise can reduce the pain experienced by older people and increase their ability to perform daily activities, such as lifting pots, sweeping, and dressing. ${ }^{14}$ Therefore, implementing the Otago exercise program can increase muscle strength, balance, well-being, and welfare of older people, impacting a better quality of life.

There were several limitations in this study. First, this pilot study's results might not be generalized to the larger population. The study participant was relatively small; thereby, the results might be inconsistent in a larger population. Second, this study only included female older adults. Mostly, male older adults have higher muscle strength than females; thus, Otago exercise program effects might differ in the male older adult population.

\section{CONCLUSION}

The Otago exercise programs can reduce the risk for falls and improve the quality of life of older people, specifically in the physical and environmental aspects. It is expected that future researchers can have a larger sample size and a longer research period so that they can determine the effects of providing the Otago exercise programs in the long run.

\section{ACKNOWLEDGMENTS}

Acknowledgements were given to the residential home care of Panti Werdha Theodora, Makassar, Indonesia, that had facilitated and allowed the researchers to conduct the study.

\section{AUTHOR CONTRIBUTIONS}

MIK conceived the study design, data collection, data analysis, and drafted the manuscript; $\mathrm{NH}$ and FA drafted the manuscript and data analysis.

\section{REFERENCES}

1. Organization WH. World report on ageing and health: World Health Organization; 2015.

2. Pengpid S, Peltzer K. Prevalence and risk factors associated with injurious falls among community-dwelling older adults in Indonesia. Current gerontology and geriatrics research. 2018;2018.

3. Rohmah AIN, Bariyah K. Kualitas hidup lanjut usia. Jurnal keperawatan. 2012;3(2).

4. Campbell A, Robertson MC. Otago exercise programme to prevent falls in older adults. Wellington: ACC Thinksafe. 2003;3.

5. Pinontoan PM, Marunduh SR, Wungouw HI. Gambaran kekuatan otot pada lansia di bplu senja cerah paniki bawah. eBiomedik. 2015;3(1).

6. Lupa AM, Hariyanto T, Ardiyani VM. Perbedaan Tingkat Keseimbangan Tubuh Antara Lansia Laki-Laki Dan Perempuan. Nursing News: Jurnal Ilmiah Keperawatan. 2017;2(1).

7. Bohannon RW. Reference values for the timed up and go test: a descriptive meta-analysis. J Geriatr Phys Ther. 2006;29(2):64-8.

8. Organization WH. Programme on mental health: WHOQOL user manual. World Health Organization; 1998.

9. Patel NN, Pachpute S. The effects of Otago exercise programme for fall prevention in elderly people. International journal of Physiotherapy. 2015;2(4):633-9.

10. Sudrajat WA. Efek pemberian latihan keseimbangan dalam mempertahankan kemampuan keseimbangan manula panti wredha rindang asih 1 ungaran. Journal of sport Science and Fitness. 2014;3(1).

11. Dirmayanti RW. Pengaruh Elastic Band Exercise Terhadap Tingkat Keseimbangan Dinamis dan Risiko Jatuh pada Lanjut Usia di Panti Sosial Tresna Werdha Gau Mabaji Gowa.

12. Salekar S, Khandale SR. Effect of Otago exercise program on balance and risk of fall in community-dwelling individuals having knee osteoarthritis. 2019.

13. Utomo B. Hubungan antara kekuatan otot dan daya tahan otot anggota gerak bawah dengan kemampuan fungsional lanjut usia: UNS (Sebelas Maret University); 2010.

14. Kiik SM, Sahar J, Permatasari H. Peningkatan kualitas hidup lanjut usia (lansia) di kota depok dengan latihan keseimbangan. Jurnal Keperawatan Indonesia. 2018;21(2):109-16.

15. Rahmawati MA, Rahayu UB. Pengaruh Otago Exercise Programme Terhadap Risiko Jatuh Pada Lanjut Usia: Universitas Muhammadiyah Surakarta; 2019.

16. Gaspar T, Cabrita T, Matos M. Psychological and social factors that influence quality of life: gender, age and professional status differences. Psychology Research. 2017;7(9):489-98.

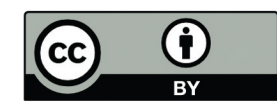

This work is licensed under a Creative Commons Attribution 